\title{
Effects of auditory stress on grooming dominance in the rat*
}

\author{
IRWIN M. SPIGEL $†$ and TENNYS MCDONALD \\ Erindale College, University of Toronto, Mississauga, Ontario, Canada
}

\begin{abstract}
Two experiments examined the effects of high-intensity white noise on the subsequent monopolization of mutual grooming by dominant members of male rat pairs. Only in cases where dominants were subjected to acoustic stress in the absence of another rat did they manifest a reduction in subsequent grooming behavior. Stressed in the company of either their own submissive partners or randomly selected rats, dominants continued to monopolize mutual grooming activity. The data emphasized the relevance of the social context in which stress is administered for the consequent social reactivity of the laboratory rat.
\end{abstract}

It has been shown by Spigel, Trivett, and Fraser (1972) that the monopolization of mutual grooming by dominant members of male rat pairs was a more stable and consistent index of social ascendancy than competition for water, the latter being more subject to variation related to the motivational state of the animal. It has also been observed that shock-induced fear does not necessarily lead to greater affiliative behavior in the laboratory rat, despite evidence that fewer signs of fear are present when animals are together than when alone (Latané, Friedman, \& Thomas, 1972). In addition, a relationship has been demonstrated (Williams \& Eichelman, 1971) between differential physiological responses, e.g., blood pressure change, in response to shock and the social setting in which the shock is administered.

The possibility that stress is reduced by manipulating social variables is suggested by the work of Morrison and Hill (1967), who found socially facilitated fear reduction in an approach-avoidance situation. In order to examine the wider implications of the relationship between social conditions and stress, the current experiments sought to determine whether established dominant-submissive relationships in male rat pairs, as measured by mutual grooming, would be affected by auditory stress under differential social settings.

\section{EXPERIMENT I}

The question raised in the first experiment was whether any differences would emerge in dominance, as manifested by grooming behavior, following periods of high-intensity noise administered with and without the presence of other rats. The aversive nature of high-intensity noise has been documented by Pinel,

*This research was financed by a grant from the National Research Council of Canada.

†Reprints may be obtained by writing Irwin M. Spigel, Erindale College, University of Toronto, Mississauga, Ontario, Canada.
Malsbury, and Corcoran (1971), Barnes and Kish (1957), and Campbell and Bloom (1965).

\section{Method}

Subjects. Forty-eight male Wistar rats ordered at 90 days of age were employed. All Ss were housed individually on reversed light cycles from arrival to the conclusion of the study, food and water remaining available at all times in home cages.

Apparatus. The grooming test chamber used was a $24 \times 24$ in. box, 18 in. high, painted gray. An IAC acoustic chamber, $23 \frac{1}{2} \times 31 \frac{11 / 2}{} \times 23$ in., was modified with a speaker fed from a Sony tape recorder containing prerecorded white noise bursts of varying durations from 3 to $15 \mathrm{sec}$. The 10 -min noise program was arranged so that the actual bursts of sound totaled $5 \mathrm{~min}$ but were delivered in a semirandom fashion over the 10-min period at $122 \mathrm{~dB}$.

Procedure. Following 1 week of laboratory habituation, rats were rank ordered by body weight, paired from the top down, and assigned in rotating order to one of four groups (six pairs to each). Pairs in all groups were then given 10-min sessions on each of 4 successive days in the grooming chamber. Rats were placed at opposite corners, and the time spent on mutual grooming was recorded. As in the original Spigel, Trivett, and Fraser (1972) experiment, Ss that groomed for the greatest proportion of the total time given over to grooming during the 4-day test period were taken to be the dominant members of pairs. Following a 3-day interval, acoustic stress and control sessions of $1 / 2-h$ duration were administered on each of 2 successive days. Dominant Ss of pairs on one group were placed in the acoustic chamber together with their respective submissives and the 122- $\mathrm{dB}$ white noise program delivered. In a second group, dominant rats received the auditory stress period alone, their submissives remaining in their home cages for the 2-day treatment period. Conditions for the third group permitted pairs to remain in the acoustic chamber for the $10-\mathrm{min}$ periods without delivery of the noise stress, while a fourth treatment allowed dominant Ss to remain alone in the chamber, noise free, their submissive partners remaining in their home cages. Posttreatment grooming retests of original pairs were carried out over the next 2 days in the grooming chamber, the mutual grooming time for each animal recorded and converted into proportions of the total actual time the Ss engaged in this activity.

Results

The sole significant posttest observation was the 
Table 1

Amount and Proportion of Time Spent Grooming by Dominant Ss During Test Sessions of Experiment I

\begin{tabular}{|c|c|c|c|c|}
\hline \multirow[b]{2}{*}{ Treatment Group } & \multicolumn{2}{|c|}{$\begin{array}{c}\text { Pretreatment } \\
\text { Grooming Time }\end{array}$} & \multicolumn{2}{|c|}{$\begin{array}{l}\text { Posttreatment } \\
\text { Grooming Time }\end{array}$} \\
\hline & $\begin{array}{r}\text { Mean } \\
(\text { Sec) }\end{array}$ & $\begin{array}{c}\text { Proportion } \\
\text { Spent by } \\
\text { Dominant } \\
\text { Ss } \\
\end{array}$ & $\begin{array}{r}\text { Mean } \\
(\mathrm{Sec})\end{array}$ & $\begin{array}{c}\text { Proportion } \\
\text { Spent by } \\
\text { Dominant } \\
\text { Ss } \\
\end{array}$ \\
\hline $\begin{array}{l}\text { Stress With Sub- } \\
\text { missive Present }\end{array}$ & 17.0 & .82 & 23.6 & .93 \\
\hline $\begin{array}{l}\text { Stress Without } \\
\text { Submissive Present }\end{array}$ & 18.2 & .75 & 6.0 & .29 \\
\hline $\begin{array}{l}\text { Nonstress With } \\
\text { Submissive Present }\end{array}$ & 18.7 & .83 & 21.3 & .82 \\
\hline $\begin{array}{l}\text { Nonstress Without } \\
\text { Submissive Present }\end{array}$ & 21.2 & .85 & 32.8 & .81 \\
\hline
\end{tabular}

striking reduction of both actual grooming time and proportion of grooming by dominant Ss that had been subjected to noise stress in the absence of their submissive partners. Mean times and proportions for all groups are shown in Table 1. F ratios of 10.83 $(\mathrm{df}=3 / 20, \mathrm{p}<.01)$ for porportionate grooming and $4.05(\mathrm{df}=3 / 20, \mathrm{p}<.05)$ for actual grooming time were obtained from the analysis of variance. Grooming times in the acoustic chamber itself by Ss in pairs given these treatments showed no differences for proportions (means of .84 and .83 for stressed and nonstressed dominants, respectively) but highly significant differences in actual amount of grooming (means of 5.5 and 19.7 , respectively).

\section{EXPERIMENT II}

The second experiment was addressed to the question of whether it is only the presence of a demonstrably "submissive" rat or the general social context in which the stressful stimulation occurs which seems to negate the decremental effect of the noise on mutual grooming.

\section{Method}

Subjects. Six ty male Wistar rats, 90 days of age at arrival, were maintained in the manner described in Experiment $I$.

Apparatus. The apparatus was the same as that described previously.

Procedure. The procedure was also as described in Experiment I, except that six groups were constituted, six pairs in each of three "stressed" groups and four pairs in each of three "nonstressed" groups. In this experiment, dominants were subjected to noise while alone in the acoustic chamber, together with their submissive, or with a randomly selected male rat of the same age but with no grooming chamber experience. Control dominants under the same social conditions but without auditory stress comprised the remaining three groups.

\section{Results}

Once again the only significant observation was the marked reduction of grooming by dominant Ss following the auditory stress sessions without a partner present (see Table 2 for mean times and proportions). There were no significant differences in grooming data among groups in pretreatment tests, nor did any differences arise in posttest grooming by dominants that had been stressed with their own submissive or with a random animal as a chamber partner. Kruskal-Wallis tests yielded $\mathrm{H}$ values of $11.27 \quad(\mathrm{p}<.01)$ and $5.0 \quad(\mathrm{p}>.05)$, respectively, for grooming scores of previously stressed and nonstressed groups. A Mann-Whiteny U test of grooming times of dominant rats stressed in the company of their submissives or random animals failed to differentiate the groups.

\section{DISCUSSION}

It is apparent from the data that the social circumstance under which noxious stimulation is experienced is more determining of consequent social relationships in male rat pairs than the antecedent stress per se. The only dominant members which showed a marked reduction in mutual grooming were those-in both the first and second experiments-which were subjected to auditory stress alone. Dominant rats stressed with either their own submissive or a randomly selected new partner tended to groom as much as or more than pretreatment levels following 122-dB noise sessions. Latané, Friedman, and Thomas (1972) observed that fear not only fails to lead to increased affiliation in rats but also that shock stress decreases attraction. Results of the current study are consistent with these observations as well as those of Hughes (1969) and point up the relevance of the social context of the stress on later grooming dominance. It might also be noted that, with the exception of the "stressed alone" condition, grooming continued to emerge as a stable index of dominance in the laboratory rat. An argument that the reduced posttreatment manifestation of grooming by dominants alone in the noise chamber is

Table 2

Amount and Proportion of Time Spent Grooming by Dominant Ss During Test Sessions of Experiment II

\begin{tabular}{|c|c|c|c|c|}
\hline \multirow[b]{2}{*}{ Treatment Group } & \multicolumn{2}{|c|}{$\begin{array}{c}\text { Pretreatment } \\
\text { Grooming Time }\end{array}$} & \multicolumn{2}{|c|}{$\begin{array}{l}\text { Post treatment } \\
\text { Grooming Time }\end{array}$} \\
\hline & $\begin{array}{r}\text { Mean } \\
(\mathrm{Sec})\end{array}$ & $\begin{array}{c}\text { Proportion } \\
\text { Spent by } \\
\text { Dominant } \\
\text { Ss } \\
\end{array}$ & $\begin{array}{r}\text { Mean } \\
(\mathrm{Sec}) \\
\end{array}$ & $\begin{array}{c}\text { Proportion } \\
\text { Spent by } \\
\text { Dominant } \\
\text { Ss }\end{array}$ \\
\hline $\begin{array}{l}\text { Stress With Sub- } \\
\text { missive Present }\end{array}$ & 25.2 & .88 & 24.5 & .96 \\
\hline $\begin{array}{l}\text { Stress Without Sub- } \\
\text { missive Present }\end{array}$ & 27.5 & .78 & 7.1 & .38 \\
\hline $\begin{array}{l}\text { Stress With Random } \\
\text { Animal Present }\end{array}$ & 17.0 & .84 & 19.5 & .90 \\
\hline $\begin{array}{l}\text { Nonstress With Sub- } \\
\text { missive Present }\end{array}$ & 24.5 & .86 & 25.8 & .84 \\
\hline $\begin{array}{l}\text { Nonstress Without } \\
\text { Submissive Present }\end{array}$ & 19.0 & .84 & 15.6 & .88 \\
\hline $\begin{array}{l}\text { Nonstress With Ran- } \\
\text { dom Animal Present }\end{array}$ & 17.6 & .77 & 17.7 & .87 \\
\hline
\end{tabular}


attributable to the mere failure to stress their submissives is countered by the fact that dominants paired with randomly selected rats continued to monopolize grooming even though their original submissive partners were also spared the $122-\mathrm{dB}$ noise sessions in the interval prior to repairing with their dominants.

Whether the social surround actually reduces the severity of the stress or serves merely to maximize the resistance of dominants to yield their social ascendancy are questions requiring further study.

\section{REFERENCES}

Barnes, G. W., \& Kish, G. B. R einforcing properties of the termination of intense auditory stimulation. Journal of
Comparative \& Physiological Psychology, 1957, 50, 40-43.

Campbell, B. A., \& Bloom, J. M. Relative aversiveness of noise and shock. Journal of Comparative \& Physiological Psychology, 1965, 60, 440-442.

Hughes, R. N. Social facilitation of locomotion and exploration in rats. British Journal of Psychology, 1969, 60, 385-388.

Latané, B., Friedman, L., \& Thomas, J. Affiliation in rats under stress. Psychonomic Science, 1972, 27, 39-40.

Morrison, B. J., \& Hill, W. F. Socially facilitated reduction of the fear response in rats raised in groups or in isolation. Journal of Comparative \& Physiological Psychology, 1967, 63, 71-76.

Pinel, J. P., Malsbury, C. W., \& Corcoran, M. E. The incubation effect produced in rats without footshock. Psychonomic Science, 1971, 24, 109-110.

Spigel, I. M., Trivett, S., \& Fraser, D. Grooming behavior and competitive dominance in the albino rat. Journal of Comparative \& Physiological Psy chology, 1972, 78, 409-411.

Williams, R. B., \& Eichelman, B. Social setting: Influence on the physiological response to electric shock in the rat. Science, $1971,174,613-614$.

(Received for publication November 27, 1973; revision received March 26, 1974.) 